\title{
Detection of conjoined placental circulation in twin fetal lambs
}

\author{
L. M. Valdes Cruz, M. J. Taylor, J. C. Mott and J. G. Carver \\ Nuffield Institute for Medical Research, University of Oxford, Headley Way, \\ Headington, Oxford OX3 9DS, U.K.
}

Conjoined placental circulations have been estimated by different workers to exist in $0.8-65 \%$ of multiple ovine pregnancies. We have examined evidence for substantial mixing of the placental circulations of unanaesthetized twin lambs late in gestation.

Experiments were carried out on the twins of a healthy ewe of mixed breed near term (126 days gestational age, full-term $\sim 147$ days). Under sterile conditions catheters were inserted into the jugular vein and carotid artery of both fetal lambs; one lamb (A) was bilaterally nephrectomized, its twin (B) remaining as a control.

To measure fetal plasma volumes, a measured weight of 5\% aqueous T1824 (Evan's Blue) was injected via the venous catheter of one fetus followed by sampling from the arterial catheters of both fetuses at set times. Plasma samples $(0.5 \mathrm{ml})$ were diluted with $2.5 \mathrm{ml} 0.15 \mathrm{M}-\mathrm{NaCl}$ and the optical density was measured at $595 \mathrm{~nm}$. The readings were corrected with measurements taken before dye injections (Caton, Wilcox, Abrams \& Barron, 1975). The experiments were conducted on 3 consecutive days, with injection of the dye into Fetus A on one occasion and into Fetus B on the other two. No dye was detected in maternal arterial plasma. The results are summarized in Table 1. They demonstrate rapid passage of dye from one fetus to the other.

Table 1. Optical density at $595 \mathrm{~nm}$ of the blood plasma of twin fetal sheep after injection of Evan's Blue

\begin{tabular}{|c|c|c|c|c|c|c|c|c|}
\hline \multicolumn{2}{|c|}{$\begin{array}{l}\text { Age of gestation } \\
\quad \text { (days) } \\
\text { Fetus injected }\end{array}$} & \multicolumn{2}{|l|}{$\begin{array}{c}133 \\
\text { B }\end{array}$} & \multicolumn{3}{|c|}{$\begin{array}{c}134 \\
\text { A }\end{array}$} & \multicolumn{2}{|c|}{$\begin{array}{c}135 \\
\text { B }\end{array}$} \\
\hline $\begin{array}{l}\text { Sampling } \\
\text { time (min) in: }\end{array}$ & Fetus A & Fetus B & Ewe & Fetus A & Fetus B & Ewe & Fetus A & Fetus B \\
\hline 0 & 0 & 0 & 0 & 0 & 0 & 0 & 0 & 0 \\
\hline 4 & & $0-280$ & & 0.219 & & & & \\
\hline 5 & & & & & & & 0.049 & $0 \cdot 180$ \\
\hline 7 & & 0.240 & & $0 \cdot 180$ & & & 0.056 & $0 \cdot 190$ \\
\hline 10 & 0.064 & 0.215 & 0 & $0 \cdot 140$ & & 0 & 0.075 & $0 \cdot 180$ \\
\hline 13 & & 0.200 & & & & & 0.070 & $0 \cdot 165$ \\
\hline 14 & & & & $0 \cdot 125$ & & & & \\
\hline 16 & & 0.185 & & & & & $0 \cdot 105$ & $0 \cdot 160$ \\
\hline 19 & & & & & & & $0 \cdot 105$ & $0 \cdot 160$ \\
\hline 27 & & & & & & & $0 \cdot 115$ & 0.130 \\
\hline 30 & & & & 0.105 & 0.075 & 0 & & \\
\hline
\end{tabular}

The arterial pressures of both fetal lambs were recorded simultaneously by using Devices Electromanometers and a Cambridge Slow Recorder; packed cell volume was measured in a sample of carotid blood. Contrary to the observations by Faber, Green \& Thornburg (1974), who found a lower arterial pressure and packed cell volume in nephrectomized than in normal fetal lambs, in the twins in this study arterial pressure and packed cell volume were similar.

Plasma angiotensin II was measured by radioimmunoassay. The nephrectomized lamb had values at the upper end of the normal range on the 3rd day after operation. In previous experiments with the same antiserum, however, angiotensin II was not detectable in nephrectomized fetal lambs (Broughton-Pipkin, Lumbers \& Mott, 1974). 
When the ewe was killed, Fetus A ( $\sigma^{\star}$, body weight $2858 \mathrm{~g}$ ) was in the right horn and Fetus B (o, body weight $2194 \mathrm{~g}$ ) was in the left. The amniotic membranes were separate. Fetus A was macroscopically normal but Fetus B was a freemartin. Although the external genitalia appeared normal, the vagina was a thin-walled, blind sac terminating at the pelvic inlet and the ovaries and both uterine horns were absent. Dissection of the placental membranes exposed an anastomosis linking the umbilical arteries of the twins (Plate 1). Others may have been present but were not sought.

Because the arterial pressures and post-mortem weights of the twin lambs were similar, equivalence of the circulating blood volumes and cardiac output was assumed. The maintenance of similar growth rates suggests that the bidirectional shunt demonstrated between them was balanced. The ratios of the plasma optical density of the recipient lamb to that of the injected one at various times after injection of dye is illustrated in Text-fig. 1. These are consistent with a bidirectional shunt of the order of $1-2 \%(10-20 \mathrm{ml} / \mathrm{min})$ of the combined ventricular output of either twin (see legend).

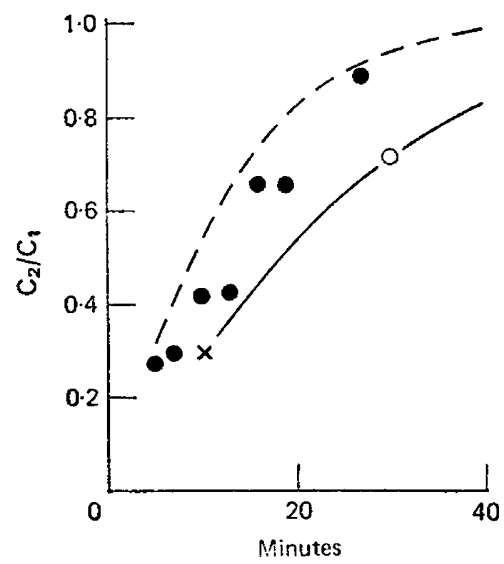

Text-fig. 1. Ratios of the concentrations of Evan's Blue in fetal sheep plasma as a function of time after injection of the dye. $C_{1}=$ optical density of plasma of the injected twin, $\mathrm{C}_{2}=$ optical density of plasma of the other twin. The curves represent $C_{2} / C_{1}$ (which is asymptotic tol), calculated from a mathematical model for shunts of $1 \%(-)$ and $2 \%(--)$ of the combined ventricular output of either twin assuming that no loss of dye occurred from the conjoined circulations. The experimentally derived points fall between these 2 curves. $\times$, Fetus B injected, 133 days; $O$, Fetus A injected, 134 days; $\bullet$, Fetus B injected, 135 days. The value taken for blood volume was $150 \mathrm{ml} / \mathrm{kg}$ body weight and for the combined output of right and left ventricles, 450 $\mathrm{ml} / \mathrm{kg} \mathrm{min}^{-1}$.

Identical experimental procedures were conducted on three further sets of fetal twin lambs. No passage of dye was detected in either direction.

Lillie (1917) and Tandler \& Keller (1911; cited by Dain, 1971) were the first to suggest that placental vascular anastomoses might be the cause of bovine freemartins. Frazer-Roberts \& Greenwood (1928) and Ewen \& Hummanson (1947) described the condition in sheep. Stormont, Weir \& Lane (1953) studied erythrocyte mosaicism in sheep and estimated that placental anastomoses occurred in $5 \%$ of multiple pregnancies while Dain $(1971,1974)$ and Dain \& Tucker $(1970)$ found the incidence of lymphocyte chimaerism to be $1-2 \%$ for their flock. Hraba, Hasek \& Cumlivsky (1956: cited by Dain, 1971) and Moore \& Rowson (1958) quote a 10-20\% incidence of skin graft tolerance among twin lambs. Kursonov (1960: cited by Dain, 1971) and Petskoi (1955: cited by Alexander \& Williams, 1964) suggested that true vascular anastomoses of allantoic vessels are present in $0.8-8 \%$ of ovine placentae but Steven (1968) recorded none in 8 twin placentae examined. Alexander \& Williams (1964) reported one ovine freemartin with a large direct arterial connection to the placenta of its male twin. Slee (1963) examined 20 placentae from multiple ovine pregnancies and noted 6 anastomoses of chorionic vessels, 3 major venous connections and 3 minor capillary vessels; skin graft tolerance occurred in $5 \%$ of cases but erythrocyte mosaicism was variable. Slee (1963) also compared the fertility of 167 ewes born twin to males to that of 187 born twin to females to unmask 
P.ATE।

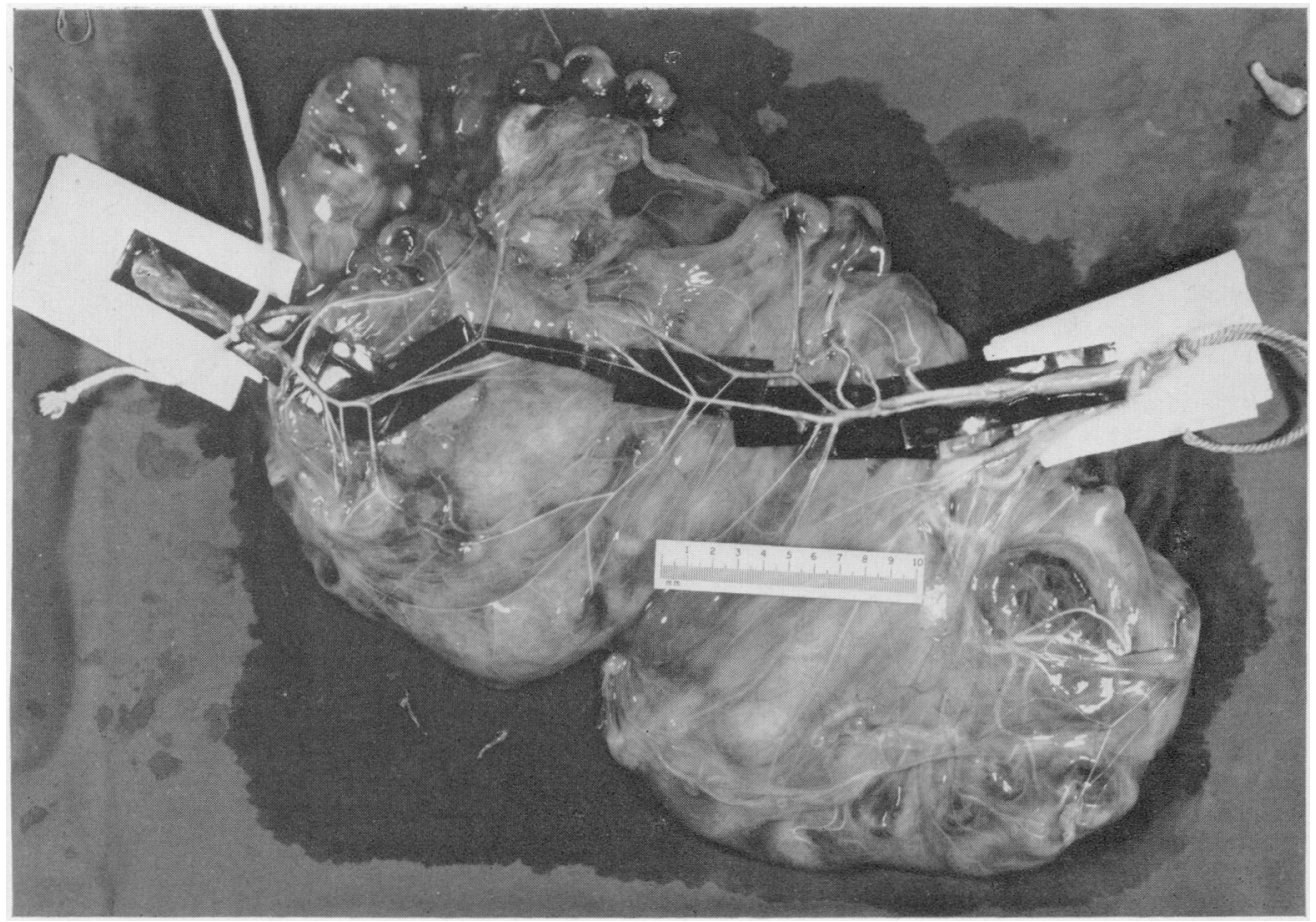

Placentae of the win lambs ath the respective umbilicat cords to right and left. An anastomosis is es ident

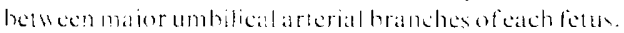


any covert infertility, but he found no statistical difference. Mellor (1969), on the other hand, quotes a $65 \%$ incidence of minor vessel fusion in placentae of British sheep breeds.

The varied estimates of the incidence of placental anastomoses cited above are based on studies on newborn and adult sheep and of placental anatomy but no firm evidence has emerged that these common channels function in late gestation. This is important because indicator dilution techniques, metabolic, endocrinological and pharmacological experiments may depend on an assumption that there is no passage of blood from one twin lamb to its sibling, which can therefore be used as a control.

By using Evan's Blue we have been able to detect a vascular anastomosis in utero. Although it was calculated that the shunt was only $1-2 \%$ of the combined ventricular output and its size was modest, substantial mixing of the blood of each fetus occurred rapidly. The possible occurrence of this anatomical variant needs to be borne in mind by workers who require definitive evidence that fetal lambs, even when of the same sex, are not interconnected.

We thank Dr D. G. Wyatt for the mathematical analysis from which the curves in Text-fig. 1 were calculated, and Mr S. Ashington for Plate 1. L.M.V.C. is a Research Fellow of the American Heart Association British Heart Foundation. M.J.T. is supported by a Research Training Scholarship from the Wellcome Foundation, and J.G.C. is supported by M.R.T. Grant G 972/841/C.

\section{References}

Alexander, G. \& Williams, D. (1964) Ovine freemartin. Nature, Lond. 201, 1296-1298.

Broughton Pipkin, F., Lumbers, E.R. \& Mott, J.C. (1974) Factors influencing plasma renin and angiotensin II in the conscious pregnant ewe and its foetus. J.Physiol., Lond. 243, 619-636.

Caton, D., WilcoX, C.J., Abrams, R. \& Barron, D.H. (1975) The circulating plasma volume of the foetal lamb as an index of its weight and rate of weight gain (g/day) in the last third of gestation. Q.Jlexp.Physiol.60,45-54.

DAIN, A.R. (1971) The incidence of freemartinism in sheep.J. Reprod. Fert. 24,91-97.

DaIn, A.R. (1974) A study of the proportions of male and female leukocytes in the blood of chimaeric sheep. J. Anat. 118, 53-59.

DaIN, A.R. \& TuCker, E.M. (1970) Cytogenetic, anatomical and blood group studies of sheep twin chimaeras. Proc. R. Soc. B 175, 183-200.

EwEN, A.H. \& Hummanson, F.A. (1947) An ovine freemartin.J. Hered.38, 149-152.

Faber, J.J., Green, T.J. \& Thornburg, K.L. (1974) Arterial blood pressure in the unanaesthetized fetal lamb after changes in fetal blood volume and haematocrit. Q.Jlexp. Physiol.59, 241-255.

Frazer-Roberts, J.A. \& Greenwood, A.W. (1928) An extreme freemartin and a freemartin-like condition in the sheep. J. Anat. 63, 87-94.

Hraba, T., Hasek, M. \& Cumlivsky, B. (1956) Immunological approximation of sheep triplets. Natural embryonic parabionts. Folia biol., Praha 2, 276-280.
Kursonov, K.M. (1960) Pseudoplacentary vascular anastomosis in embryonic parabionts and the appearance of freemartinism in sheep. Dokl. (Proc.) Acad. Sci. U.S.S.R. Biol. Sci. Section 134, 711-716.

LILLIE, F.R. (1917) The freemartin: a study of the action of sex hormones in the foetal life of cattle. $J$. exp. Zool. 23, 371-421.

MELLOR, D.J. (1969) Vascular anastomosis and fusion of foetal membranes in multiple pregnancy in the sheep. Res. vet. Sci. 10, 361-367.

MOORE, N.W. \& Rowson, L.E.A. (1958) Freemartins in sheep. Nature, Lond. 182, 1754-1755.

PersKoI, P.G. (1955) Embryonic parabiosis in multiple births in agricultural animals. Proc. Severtosov. Inst. Anim. Morph. 14, 44-47.

SLEE, J. (1963) Immunological tolerance between littermates in sheep. Nature, Lond. 200, 654-656.

StEVEN, D.H. (1968) Placental vessels in the foetal lamb. J. Anat. 103, 539-552.

Stormont, C., Weir, W.C. \& LANE, L.L. (1953) Erythrocyte mosaicism in a pair of sheep twins. Science, N.Y.118, 695-696.

TANDler, J. \& Keller, K. (1911) Über das Verhalten das Chorions bei verschiedengeschlechtlicher Zwillingsgravidität des Rindes und über die Morphologie des Genitales der weiblichen Tiere, welche einer solchen Gravidität entstammer. Dt. tierärztl. Wschr. 19, 148-154. 